\title{
Enhancing the Cultural Soft Power, Building a Strong Cultural Province
}

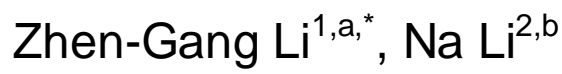 \\ ${ }^{1}$ Propaganda Department, of North China Institute of Aerospace Engineering, Langfang, Hebei, \\ China \\ ${ }^{2}$ Ideological and political education of graduate students of College of law and Politics of Hebei \\ Normal University, Shijiazhuang, Hebei, China \\ alzg2009314@sina.com, bnana88866686@sina.com \\ ${ }^{*}$ Corresponding author
}

Keywords: Culture, Soft power.

\begin{abstract}
Cultural soft power is an important part of the city's comprehensive strength; Hebei Province is a big province of cultural resources, having made considerable progress in cultural construction. But some problems still exist, the construction of cultural province must be based on the situation of Hebei Province and emphasize the basic function of hard power. At the same time, of equal importance are enhancing the development of philosophy, promoting the construction of core value system and carrying forward the national excellent traditional culture while promoting cultural innovation, and optimizing the system and improving the mechanism, to provide system security.
\end{abstract}

\section{Introduction}

In today's world, a variety of cultural exchanges have become more frequent. Our country is in the transition period of social development which is from focusing on economic development to the economic and cultural paragenesis harmonious direction transformation and culture has been largely emphasized. In this situation, it is of great importance and urgency to comprehensively enhance China's cultural soft power, energetically develop an advanced socialist culture and the construction of the socialist core value system. Hebei is a big province of cultural resources, having a long history, along with a glorious revolutionary culture. The construction of a cultural province has a good foundation and condition. At the same time, due to China's international status has improved significantly and expanded international influence, all countries in the world are generally optimistic about the prospects for the development of China, desiring to cooperate with China each passing day, so we could learn from the outstanding achievements of word favorable civilization to build ourselves stronger. We must seize this opportunity, comprehensively enhancing the cultural soft power of our province, and promote Chinese culture better than the world level.

\section{Cultural soft power}

The soft strength of culture refers to the culture related part of soft power, which comprises the core values of cohesion, cultural brand creativity, cultural image and cultural environment affinity attraction etc, which constitute the integrated effect of cultural soft power. And it is not only a struggle process of city competition, but also the constant pursuit of the perfect target.

"Soft power" first appeared in the party and the national document report in 2006. Hu Jintao said: "It is an important realistic subject in front of us to find the development of China's cultural orientation, create new brilliance of national culture and enhance the international competitiveness of China's culture while improve the national soft strength," which was emphasized on china Wendaihui and Zuodaihui .

The party's eighteen reports put forward clearly "improving the national cultural soft power", "vigorously develop the cultural industry, the prosperity of the cultural market, enhance the international competitiveness" and other important discuss, demonstrating that Chinese government has established significant strategy of "promote cultural soft strength" from the national level, which fully reflects our party's scientific understanding and position on the development trend of the times and the China's cultural development direction. 


\section{The background of construction policy of strengthening province of Hebei}

\section{The cultural construction is an important component of China's socialist modernization construction.}

Cultural soft power is an important part of the city's comprehensive strength. It has a kind of appeal, which can form a great centripetal force and cohesion. As an important part of the comprehensive development of the society, Enhancing the cultural soft power matches the Hebei culture soft power and the basic situation of economic social, builds perfect function, coordination of the system of public cultural services, cultural industry system, promotes cultural development and prosperity, which all have an important strategic significance for Hebei. To grasp the initiative in the field of ideology, it is essential to the rulling to give full play to the guiding role of culture. At the same time, doing a good job of cultural construction is a necessary requirement to achieve the construction of economic strong province, and a strategic goal of harmonious Hebei.

\section{The correct understanding of basic province Hebei is big province of cultural resources}

Understanding and grasping the situation correctly is the promise to realize leaping development. Provincial Party committee's judgment on our province is a big province of cultural resources, which is consistent with the actual situation of our province, revealing the phase characteristics of the cultural development in our province. Our province is a big province of cultural resources, having a good foundation and condition of leapfrog development. But there is a large gap refers to cultural strong province, needing to be paid the long-term and arduous efforts. We must base on the basic situation of the province to study the culture work and plan the development of culture, consciously constructing our province from big of cultural resources province to strong cultural province

\section{The positioning and target of the construction of Hebei strong cultural province}

Provincial Party committee clearly put forward the implementation of the big province of cultural resources to strong cultural province, walking out of China characteristics. The characteristics of the Hebei province culture construction of the road, is to adhere to the orientation of advanced socialist culture Chinese characteristics, from Hebei reality, adhere to the top-level design, planning ahead, landing the project, construct overall pattern of development of cultural undertakings and cultural industries development, urban and rural cultural integration development, cultural and economic integration, enhancing the core competitiveness of cultural development in Hebei.

The construction of cultural province is a long-term strategic goal of our province culture construction, which should be based on the great practice of building the strong province of economy, harmonious Hebei, give full play to the leading role of fashion culture, educate people, promote the development of the socialist core values, do strong cohesion, cultural system and mechanism innovation and strong, the competitiveness of cultural industry, make deep inside, infinite vitality of the Yanzhao culture, shine more brilliantly.

\section{The present situation of Hebei cultural construction}

In recent years, the cultural construction in Hebei has made considerable development, and it has its own unique advantages. Hebei has lots of cultural relics, which is also rich in cultural resources and has an inexhaustible cultural resources to enhance the cultural soft power; Hebei is around Beijing, which is called the capital of "moat", making it have be richly endowed by nature geographical advantage; strong economic development momentum and strong comprehensive strength are an important guarantee to enhance the cultural soft power; Walking in the forefront of the system reform and innovation, is an important measure to enhance the cultural soft power. However, from a more consciously, actively promote the prosperity of the socialist culture development requirements, there are still some uncoordinated exist in our province culture construction, not comprehensive questions, affecting the overall promotion of our province's cultural soft power, such as in some places, there is an emphasis on economy development yet despise culture, emphasis on mining and finishing of the culture yet despise the construction of culture resources. 


\section{Discussion on the path of promoting cultural soft power and building a strong cultural province}

\section{Enhance the development idea, promoting the construction of core value system}

We should adhere to the construction of socialist core value system as the basic point, and constantly improve the cohesion of advanced cultural. The socialist core value system is the essence of advanced socialist culture, the fundamental and the core of building a strong culture. Cultural soft power in large shown as the national state of mind, willpower and internal cohesion, and all of this comes from people's recognition of social core value. Therefore, we should consider the construction of the socialist core value system as the first task of improving the national cultural soft power, arm and educate people with the newest achievement of the sinicizating of Marxism.

\section{Carry forward the fine traditional culture of ethnic cultural heritage, to strengthen the culture heritage force and build the culture brand.}

Hebei has a long history, which is an important birthplace of Chinese civilization, the Yanzhao sons and daughters on this piece of land created not only great splendor history and culture, but also great red culture. Hebei province should dig deep cultural resources, comb cultural vein system and build five major cultural brand of Hebei culture of "red Taihang, magnificent the Great Wall, sincerity of YanZhao, verve BeiJing, frolic waves of BoHai ", shift the unique resource advantage into effective cultural development advantages, adhere to the inheritance and development of innovation, vigorously carry forward the essence of traditional culture, combined with the construction of economic strong province, the great practice of harmonious Hebei, endowed with new connotation and the spirit of the times, constantly sum up and refine, carry forward.

To improve the cultural soft power, and actively promote cultural innovation, strengthen cultural development vigor and vitality

Adhere to the construction of modern culture industry as a support point system; continuously improve the competitiveness of the cultural industry. We should actively promote the big project culture big platforms construction industry of large enterprises, the formation of a group of influential in the national or provincial cultural leading enterprises, create a group with strong gathering and driving function of the cultural industry park, and gradually form the distinctive characteristics, situation is good, with great potential of cultural industry development pattern, lead and drive the cultural industry in our province to achieve leapfrog development.

Improving the city's cultural soft power is a long-term and systematic project, which we cannot do without for guidance of government and the whole society. Cultural construction has its own characteristics, which can not be accomplished at one stroke, need to move work steadily. We should strengthen the research and make scientific decision to build Hebei into regional economic, cultural center of the city, build perfect function, coordination of the system of public cultural services, cultural industry system and cultural market system. Promote Hebei in the country's cultural competitiveness, which among the national cultural province list.

\section{References}

[1] Zhang Daoping, Ways to enhance the cultural soft power, Journal of Economist vol, 11, 2010, PP.49- 50 .

[2] Chen Shaofeng, Countermeasures thinking of enhancing the city's cultural soft power, Journal of Fujian Forum(Humanities and Social Sciences), vol.10,2011,PP.17- 20.

[3]LIU Tao, and YAN Yan-fang, Ring the Capital economic circle of Langfang city under the background of humanism, Journal of North China Institute of Aerospace Industry, vol.21, 2011, PP.36. 